\title{
Investigation of the Relationship between Organizational Trust and Organizational Commitment
}

\author{
Gülsüm Baştug ${ }^{1}$, Adem Pala ${ }^{1, *}$, Mehmet Kumartaşli ${ }^{2}$, İker Günel ${ }^{3}$, Mehdi Duyan ${ }^{3}$ \\ ${ }^{1}$ Faculty of Sports Sciences, Mugla Sitki Kocman University, Turkey \\ ${ }^{2}$ School of Physical Education and Sports, Suleyman Demirel University, Turkey \\ ${ }^{3}$ Institution of Healthy Sciences, Mugla Sitki Kocman University, Turkey
}

Copyright $\odot 2016$ by authors, all rights reserved. Authors agree that this article remains permanently open access under the terms of the Creative Commons Attribution License 4.0 International License

\begin{abstract}
Organizational trust and organizational commitment are considered as the most important entraining factors for organizational success. The most important factor in the formation of organizational commitment is trust that employees have in their organizations. In this study, the relationship between organizational trust and organizational commitment was searched. For this purpose, 176 sports employees of Provincial Directorate of Youth and Sports in Turkey were applied "organizational trust scale" developed by Omarov [33] as well as "organizational commitment scale" developed by Meyer and Allen [26]. The data obtained as a result of the research were analyzed by SPSS 20.0 software program and the results were presented. As a result, it is remarkable that emotional commitment of male employees was more than that of female employees. Trust of participants in director positively affected emotional and normative commitment. It was also determined that trust of participants in their colleagues and organizations positively affected normative (commitment to worth and targets of the organization) commitment. It was concluded that organizational trust positively affected organizational commitment in sports employees.
\end{abstract}

Keywords Organizational, Trust and Commitment, Sports Employees

\section{Introduction}

In modern organizations, it can be observed that less hierarchical stages are present between administrating and administered, high level of participation is supplied and trust gains importance in inter-organizational relationships. Leaguing of people having different characteristics and skills together around similar purposes and performing this with high level of participation and with trust to a large extent gradually becomes even more important. For this reason, providing the trust feeling in organization and between the members of organization is confronted as a necessity [10]. Trust can be defined as people displaying behaviors mutually with each other as part of the scope of universal moral rules [30]. Organizational trust is a discrete but concretizing process with behaviors of individuals in an organizational structure in a feeling of accuracy, belief, commitment and sincerity to each other [2]. Inter-organization trust plays an important role in organizational activities and periods such as cooperative behavior development, performance evaluation, setting an objective, leadership, and formation of team spirit, organizational commitment and contribution to the satisfaction of employee [16].

Organizational Trust: Providing organizational trust in organizations, it's possible to mention three dimensions such as trust in institution, trust in director and trust in colleagues [21]. Trust in director is a belief for him to keep his promises, to behave consistently and fairly, to give clear and correct answers [11]. For creating environment of trust, it's necessary for administration to configure the feeling of trust in all employees of the organization and to direct them very carefully. The directors might develop trust or lose trust in organization with all what he did and applied as well as what he promised[35]. As an important representative of the organization, the factors such as coherence of the director's behaviors, having integrity in what he said and did, allowing participation and sharing control, clarifying given decisions by giving correct information, establishing an open communication with employees, considering what is best for the employees are assumed to affect the trust in director [33]. The process of organizational trust creation in public organizations is the responsibility of qualified managers and leaders. The role of managers and leaders in organization is of great importance. For successful feedback and observation of advanced organizational behavior, we need high level of interpersonal trust among the co-workers in organization [4]. The success, effectiveness and efficiency of organizations mostly depend on the trust of employees with each other in organizations. Lack of trust feeling, on the other hand, tarnishes the relations in the work environment. 
It is not possible for people who are acting with suspicion towards each other to reveal a successful work at the end [5]. Trust in organization is a belief about consistent subscription and behaviours of organization when employees confront with an unspecified or risky situation [8]. For organizational trust, employees take a great leap of faith for the present and future state of their organization and conduct their job within this perspective. In turn, this trust helps increase in job satisfaction, productivity and performance (Akdere et al.[1]; Vineburgh [44]). Organizational trust is of great importance in success of organizations. Trust is an important issue for most organizations as it can have great advantages for organization. Organizational trust is defined as psychological state providing a feedback of how employees perceive the problems in the situations in which the organization is endangered [43]. It's expected with high level trust to result in high level business manners (work satisfaction, organizational commitment, etc.), positive organizational behaviours (such as organizational citizenship behaviour) and high level performance [9].

Organizational Commitment: The organizational commitment is considered to be a bond or linking between the individual and the organization [24]. Organizational commitment, on the other hand, is 'the relative strength of an individual's identification with and involvement in a particular organization [31]. Meyer and Allen [26] categorized the nature of such psychological state in three components: affective, continuance and normative commitment. Affective commitment is an attitudinal process whereby individuals come to think about their relationship to the organizations with respect to values and goals. It involves 'employees' emotional attachment to, identification with, and involvement in the organization. Organizations with employees of high affective commitment levels retain their employees because these employees simply want to work there. Continuance commitment refers to 'an awareness of the costs associated with leaving the organization. Organizations with employees of high continuance commitment levels retain their employees because these employees need to stay in the organization for the time being until they probably find a better or more suitable job for themselves. Normative commitment, on the other hand, reflects a feeling of obligation to continue in a job position based on employee's personal values and beliefs [23, [28], [29]. Meyer and Allen [28] did not indicate what the ideal, expected or average commitment level should be related with emotional, continuance and normative commitment. Shaw [38] identified three dimensions of organizational commitment: affective, continuance and normative commitment. Positive, sincere and utmost involvement of employee for its organization is called affective commitment. Emotional commitment is an emotional intimacy feeling as reflected in the sentence of "I'm working here because the people here are awesome and the work is so entertaining". Continuance commitment is a feeling which manifests itself in situations which might cause many problems if the work is changed such as reflected in the sentence of "If I can find another job with the same salary, I immediately leave the work. Normative commitment, on the other hand, describes the commitment towards the worth and objectives of the organization and is a feeling of obligation as reflected in the sentence of "I'm working here because they employed me when I needed a job, I'm in debt [38]. In all studies performed, whether organizational commitment had positive or negative relationship with various factors was investigated. Besides, it was determined that the most desired situation is primarily high emotional commitment of employees, then normative commitment and finally continuance commitment [6]. Organizational commitment is described widely in management and literature of organizational behavior as key factor in relations between people and organizations. Organizational commitment can lead to useful outcomes as increasing the effectiveness, efficiency and productivity and reduction of trading volume and absence in individual and organizational levels [18]. Khorshid and Yazdani [20] in a study where "the investigation of the relationship between trust, contrast and organizational belonging by considering the moderating impact of organizational commitment" was investigated found that trust of employees to organization and contrast norms in organization had positive and significant impact on trust of employees. In addition, among various dimensions of organizational commitment, emotional commitment of employees to organization, the relations of trust of employees to organization with their organizational belonging and duality norms in organization adjust organizational belonging of employees positively and significantly. Bahrami et al.[3] indicated a positive and significant correlation between organizational commitment and organizational climate. Also other results showed that there are significant positive relationship between avoidance of organizational climate with affective commitment and focus on production with normative and continues commitment. Behaving of employees within organization with an awareness of being a part of this organization improves the level of contribution they had to the organization in both qualitatively and quantitatively. This is the main reason why this commitment is so important for the organization [13]. Organizational commitment is the strongest motivator that highly affects persons' intentions to perform well, increases his efficiency, and improves his skills. Organizational commitment is important for organizations because it is a good predictor of organizational goals and objectives, productivity, absenteeism and turnover [40]. Perceiving fair treatment and support applied by organization also affects organizational commitment together with this created trust [32].

Organizational trust and organizational commitment have importance in keeping the performance in organizations at high level and in getting desired results in terms of organizations. Organizational trust and organizational commitment are the most important driving forces for 
organizational success. In this regard, the main purpose of this study was to investigate the organizational trust and organizational commitment relationship sports employees.

\section{Materials and Methods}

\section{Participants}

In this study where the relationship between organizational trust and organizational commitment was investigated, totally 179 sports employees including 54 females and 125 males working in Antalya, Kütahya and Karaman Provincial Directorate of Youth and Sports in Turkey were voluntarily participated.

\section{Data Collection Tools}

In order to determine organizational trust level of participants, "Organizational Trust Scale" developed by Omarov [33] was used whereas "Organizational Commitment Questionnaire" developed by Meyer and Allen [26] was used to determine the level of organizational commitment. For measuring the organizational trust level of participants in the research was used.

\section{Organizational Trust Scale}

The scale which was used by Omarov [33] in his study titled with "Organizational Trust and Work Satisfaction: An Application in Private Sector" was benefited. There are three factors being about trust in director, trust in colleagues and trust in organization itself. Trust in Director: The questions between 1-10, Trust in Colleagues: questions between 11-15, Trust in Organization itself: questions between 16-22. The answers for the questions in 22 question-scale were given in 5 point likert scale such as; 1-Absolutely not agree, 2- Not agree, 3-Undecided, 4-Agree, 5- Absolutely agree. The results of the scale were distributed in a range of $5.00-1.00=4.00$ points. This range was divided into five and the levels determining the breakpoints of the scale were indicated. According to this, it was "very low" between 1.00-1.79 points, it was evaluated as "low" between $1.80-2.59$, it was "medium" between 2.60-3.39 points, it was assessed as "high" between 3.40-4.19 points and it was "very high" in the range of 4.20-5.00 points.

\section{Organizational Commitment Questionnaire}

In order to determine the organizational commitment of participants, Organizational Commitment Questionnaire was used which was developed by Meyer and Allen [25], was reconsidered by Meyer, Allen and Smith [27] and adapted to Turkish by Wasti [45]. The scale was constituted of three dimensions such as emotional commitment, continuance commitment and normative commitment as well as 18 items four of which were negative. Emotional commitment expresses the positive interaction originated from similar values between organization and the employee. The expressions related with emotional commitment in the scale were in the questions numbered with 1,2, 3 and $16,17,18$. In continuance commitment, the employee considers that he/she wastes time and effort exceedingly, makes investment for the organization, and as a result of this it is an obligatory to stay in the organization. The expressions related with continuance commitment in the scale were in the questions numbered with 4, 5, 6, 7, 8, 9. In normative (gratefulness) commitment, on the other hand, the employee is a belief that he/she should stay in the organization. These people think that they are obliged to their employers and as a result of the sense of obligation, it expresses he/she desires to continue working within the organization. The expressions related with normative commitment in the scale were in the questions numbered with $10,11,12,13,14,15$. [12]. Wasti [45] revealed that Turkish version of the scale confirms three dimensional structure in its original form and factor load values of scale items changed within 0.20 and 0.72 . Moreover, the reliability coefficients were calculated as 0.78 , 0.75 and 0.58 for emotional commitment, normative commitment and continuance commitment, respectively [45].

\section{Hypotheses of the research}

H1: There are differences organizational trust and commitment by gender.

$\mathrm{H} 2$ : There are relationship between organizational trust and organizational commitment.

Tables were formed and interpreted according to these results.

\section{Statistical Analyses of the Research}

For the analysis of the data, SPSS 20.0 statistical software program was used. For the evaluation of the data, average, standard deviation, frequency and percentage statistics as well as $\mathrm{t}$ test, correlation and regression analysis were utilized.

\section{Findings}

Table 1. Demographical Information of Participants

\begin{tabular}{|c|c|c|}
\hline Gender & $\mathbf{n}$ & $\mathbf{\%}$ \\
\hline Female & 54 & 30.2 \\
\hline Male & 125 & 69.8 \\
\hline Total & 179 & 100.0 \\
\hline Age & $\mathrm{N}$ & $\%$ \\
\hline $25-30$ & 54 & 30.2 \\
\hline $31-35$ & 45 & 25.1 \\
\hline $36-40$ & 37 & 20.7 \\
\hline $41-45$ & 17 & 9.5 \\
\hline $46-50$ & 15 & 8.4 \\
\hline 51 and over 51 & 11 & 6.1 \\
\hline Total & 179 & 100.0 \\
\hline
\end{tabular}


As it can be seen in Table 2, a significant difference was found between organizational trust sub-dimension and trust in colleagues in terms of gender $(p<0.05)$. The average values of trust in colleagues for female employees (18.75 \pm $5.20)$ and for male employees $(18.94 \pm 4.35)$ were very close to each other. A significant difference was not found between trust in director in organization and trust in organization in terms of gender $(p>0.05)$. There was a significant difference between emotional commitment sub-dimension of organizational commitment and gender $(p<0.05)$. Average value of emotional commitment to organization for females was $(22.70 \pm 8.35)$ while it was found as $(25.63 \pm 8.29)$ for males. This indicates that emotional commitment of males to their organization was higher than that of females. A significant difference was not found between continuance commitment in organization and normative commitment in terms of gender $(\mathrm{p}>0.05)$.

As it can be seen in Table 3, a significant relationship was found between trust in director, emotional commitment and continuance commitment $(p<0.05)$. There was also a significant relationship between trust in colleagues, emotional commitment and continuance commitment $(p<0.05)$. A significant relationship was also indicated between trust in organization, emotional commitment and continuance commitment $(\mathrm{p}<0.05)$. A significant relationship was not found between organizational trust sub-dimensions and normative commitment ( $p>0.05)$.

Table 2. Investigation of Organizational Trust and Organizational Commitment Properties of Participants in terms of Gender Variable

\begin{tabular}{|c|c|c|c|c|c|c|}
\hline & Sub-Dimensions & Gender & $\mathbf{n}$ & $\mathbf{X} \pm \mathbf{S S}$ & $\mathbf{t}$ & $\mathbf{p}$ \\
\hline \multirow{6}{*}{$\begin{array}{c}\text { Organizational } \\
\text { Trust }\end{array}$} & \multirow{2}{*}{ Trust in Director } & Female & 54 & $36.05 \pm 8.74$ & \multirow{2}{*}{0.984} & \multirow{2}{*}{0.684} \\
\hline & & Male & 125 & $37.52 \pm 9.37$ & & \\
\hline & \multirow{2}{*}{ Trust in Colleagues } & Female & 54 & $18.75 \pm 5.20$ & \multirow{2}{*}{0.491} & \multirow{2}{*}{$0.26^{*}$} \\
\hline & & Male & 125 & $18.94 \pm 4.35$ & & \\
\hline & \multirow{2}{*}{ Trust in Organization } & Female & 54 & $20.44 \pm 6.40$ & \multirow{2}{*}{0.567} & \multirow{2}{*}{0.941} \\
\hline & & Male & 125 & $21.07 \pm 6.96$ & & \\
\hline \multirow{6}{*}{$\begin{array}{c}\text { Organizational } \\
\text { Commitment }\end{array}$} & \multirow{2}{*}{ Emotional Commitment } & Female & 54 & $22.70 \pm 8.35$ & \multirow{2}{*}{2.162} & \multirow{2}{*}{$0.33 *$} \\
\hline & & Male & 125 & $25.63 \pm 8.29$ & & \\
\hline & \multirow{2}{*}{ Continuance Commitment } & Female & 54 & $22.61 \pm 6.99$ & \multirow{2}{*}{0.482} & \multirow{2}{*}{0.630} \\
\hline & & Male & 125 & $23.11 \pm 6.09$ & & \\
\hline & \multirow{2}{*}{ Normative Commitment } & Female & 54 & $20.46 \pm 6.40$ & \multirow{2}{*}{0.567} & \multirow{2}{*}{0.577} \\
\hline & & Male & 125 & $21.09 \pm 6.96$ & & \\
\hline
\end{tabular}

$\mathrm{p}<0.05$

Table 3. Investigation of the Relationship between Organizational Trust and Organizational Commitment of Participants

\begin{tabular}{|c|c|c|c|c|}
\hline Organizational Trust Sub-Dimensions & $\begin{array}{c}\text { Organizational Commitment } \\
\text { Sub-Dimensions }\end{array}$ & $\mathrm{n}$ & $\mathrm{r}$ & $\mathrm{p}$ \\
\hline \multirow{3}{*}{ Trust in Director } & Emotional Commitment & 179 & .49 & $.000^{*}$ \\
\hline & Continuance Commitment & 179 & .33 & $.000 *$ \\
\hline & Normative Commitment & 179 & .086 & .253 \\
\hline \multirow{3}{*}{ Trust in Colleagues } & Emotional Commitment & 179 & .30 & $.000 *$ \\
\hline & Continuance Commitment & 179 & .26 & $.000^{*}$ \\
\hline & Normative Commitment & 179 & .018 & .018 \\
\hline \multirow{3}{*}{ Trust in Organization } & Emotional Commitment & 179 & .50 & $000^{*}$ \\
\hline & Continuance Commitment & 179 & .32 & $000^{*}$ \\
\hline & Normative Commitment & 179 & .189 & .011 \\
\hline
\end{tabular}


Table 4. Investigation of the Relationship between Organizational Trust Sub-Dimensions (Trust in Director - Trust in Colleagues - Trust in Organization) and Organizational Commitment Sub-Dimensions (Emotional Commitment, Continuance Commitment, Normative Commitment) of Participants

\begin{tabular}{|c|c|c|c|c|c|c|c|}
\hline Dependent Variable & Independent Variable & $\beta$ & $\mathrm{t}$ & $\mathrm{p}$ & $\mathrm{F}$ & $\begin{array}{l}\text { Model } \\
\text { (P) }\end{array}$ & $\mathrm{R}^{2}$ \\
\hline & Constant & .901 & .319 & .750 & \multirow{4}{*}{27.822} & \multirow{4}{*}{$.000^{*}$} & \multirow{4}{*}{.32} \\
\hline \multirow{3}{*}{ Trust in Director } & Emotional Commitment & .249 & 3.300 & $.001^{*}$ & & & \\
\hline & Continuance Commitment & .141 & 1.087 & .278 & & & \\
\hline & Normative Commitment & .665 & 4.374 & $.000^{*}$ & & & \\
\hline & Constant & 10.035 & 4.195 & .000 & \multirow{4}{*}{10.414} & \multirow{4}{*}{$.000^{*}$} & \multirow{4}{*}{.15} \\
\hline \multirow{4}{*}{ Trust in Colleagues } & Emotional Commitment & .106 & 1.663 & .098 & & & \\
\hline & Continuance Commitment & .179 & 1.624 & .106 & & & \\
\hline & Normative Commitment & .312 & 2.423 & .016 & & & \\
\hline & Constant & 16.132 & 5.933 & .000 & \multirow{4}{*}{2.252} & \multirow{4}{*}{.084} & \multirow{4}{*}{.037} \\
\hline \multirow{3}{*}{ Trust in Organization } & Emotional Commitment & -.009 & -.119 & .905 & & & \\
\hline & Continuance Commitment & -.052 & -.416 & .678 & & & \\
\hline & Normative Commitment & .337 & 2.298 & .023 & & & \\
\hline
\end{tabular}

$\mathrm{p}<0.05$

As it can be seen in Table 4, a significant relationship was found between trust in director, emotional commitment and normative commitment $(\mathrm{p}<0.05)$. Trusting of participants in director positively affected emotional commitment and normative commitment. There was also a significant relationship between trust in colleagues and normative commitment $(\mathrm{p}<0.05)$. It was determined that trusting of participants in their colleagues positively affected normative (commitment to values and objectives of the organization) commitment. A significant relationship was also found between trust in organization and normative commitment $(p<0.05)$. It was stated that trusting of participants in their organizations positively affected normative (commitment to values and objectives of the organization) commitment.

\section{Discussion and Conclusions}

In this study where the relationship between organizational trust and organizational commitment was investigated, the following findings were found;

A significant difference was found between trust in colleagues and gender. The average values of trust in colleagues for female employees $(18.75 \pm 5.20)$ and for male employees $(18.94 \pm 4.35)$ were very close to each other. A significant difference was not found between trust in director in organization and trust in organization in terms of gender $(p>0.05)$. There was a significant difference between emotional commitment sub-dimension of organizational commitment and gender. Average value of emotional commitment to organization for females was $(22.70 \pm 8.35)$ while it was found as $(25.63 \pm 8.29)$ for males. This indicates that emotional commitment of males to their organization was higher than that of females. A significant difference was not found between continuance commitment in organization and normative commitment in terms of gender (Table 2). When organizational commitment levels of directors and teachers were investigated in terms of gender, it was found that the females experienced less emotional commitment than the males [15]. In another study where the relationship between organizational justice, trust and work satisfaction was investigated, it was determined that there was a positive relationship between organizational justice, trust and work satisfaction [17]. Top et al., [41] reported that, organizational trust has a significant effect on overall organizational commitment as well as its three dimensions for public servants and private employees. Lambert et al. [22] reported that, significant relationship between age, gender and educational levels to job stress and organizational commitment in a research.

A significant relationship was found between trust in director, emotional commitment and continuance commitment. There was also a significant relationship between trust in colleagues, emotional commitment and continuance commitment. A significant relationship was also indicated between trust in organization, emotional commitment and continuance commitment. A significant relationship was not found between organizational trust sub-dimensions and normative commitment (Table 3). Sheik-Mohammad et al., [37] performed a study regarding the significance of the relationship between organizational trust, job satisfaction and organizational commitment. There are many factors affecting organizational commitment. These are; age, gender, experience, organizational justice, trust, work satisfaction, role conflict, importance of performed work, support received, participation in resolution process, taking part in work, work safety, recognition, alienation, marital status, rights supplied except salary, desperation, work hours, grants, routinization, promotion opportunities, salary, other transactors, leadership behaviours, external work opportunities and interest in transactors [7].

A significant relationship was found between trust in director, emotional commitment and normative commitment. 
Trusting of participants in director positively affected emotional commitment and normative commitment. There was also a significant relationship between trust in colleagues and normative commitment. It was determined that trusting of participants in their colleagues positively affected normative (commitment to values and objectives of the organization) commitment. A significant relationship was also found between trust in organization and normative commitment. It was stated that trusting of participants in their organizations positively affected normative (commitment to values and objectives of the organization) commitment (Table 4). Khatibi, et al. [19] indicated that a negative significant relationship was found between job stress and organizational commitment, affective commitment and normative commitment, but there was not a significant relationship between job stress and continuance commitment. Yildiz [46] reported that the influence of internal marketing on organizational commitment was partially mediated through job satisfaction. It was determined in the study of Topaloğlu [42] that trust has an improvement effect on organizational commitment of employees. The employees' trusts to their organizations continue on their organization membership voluntarily and adopt the objectives of organizations better. Bakiev [4] found in a study titled with "the impact of interpersonal trust and organizational commitment on organizational perception performance" that there was a positive and significant relationship between interpersonal trust and organizational commitment. The results of studies showed that interpersonal trust in employees and creating trustful climate led into high level of commitment and performance improvement. Fard and Fariba [14] indicated that, organizational trust had direct impact on organizational silence, organizational commitment and job satisfaction and had indirect impact via organizational silence on organizational commitment and job satisfaction. Also, organizational silence had direct impact on organizational commitment and job satisfaction. It was determined that trust had effect on organizational commitment and there was a positive relationship between trust and organizational commitment [34]. Taşkın and Dilek [39] reported that there was a strong relationship between organizational trust, emotional commitment and normative commitment. There wasn't a significant relationship between organizational trust and continuance commitment. These studies are in accordance with our research.

Consequently; a significant relationship was found between trust in colleagues and gender. A significant difference was not found between trust in director, trust in organization and gender. There was also a significant difference between emotional commitment and gender. It is remarkable that emotional commitment of male employees was more than that of female employees. A significant relationship was also indicated between trust in organization, emotional commitment and continuance commitment. A significant relationship was found between trust in director, emotional commitment and normative commitment. There was also a significant relationship between trust in colleagues, organizational trust and normative commitment. A significant relationship was not found between organizational trust sub-dimensions and normative commitment. Trusting of participants in director positively affected emotional commitment and normative commitment. It was determined that trusting of participants in their colleagues and organization positively affected normative (commitment to values and objectives of the organization) commitment. It was also concluded that organizational trust in sports employees positively affected organizational commitment.

\section{REFERENCES}

[1] Akdere, M., Gider, O., \& Top, M. (2012). Examining the role of employee focus in the Turkish healthcare industry. Total Quality Management \& Business Excellence, 23, 1241-1256.

[2] Arslan, M.M. (2009). Organizational trust perceptions of teachers in Technical and Industrial Vocational High Schools. Theory and Application in Education, 5 (2), 274-288.

[3] Bahrami, M.A., Barati, O., Ghoroghchian, M.S.,Montazer-alfaraj, R., Ezzatabadi, M.R. (2015) Role of organizational climate on organizational commitment: the case of teaching hospitals, Osong Public Health and Research Perspectives, In Press, Accepted Manuscript.

[4] Bakiev, E. (2013). The influence of interpersonal trust and organizational commitment on perceived organizational performance. Journal of Applied Economics and Business Research, 3(3), 166-180.

[5] Bilgiç, Ö. (2011). Perception of primary schhol teachers related with organizational trust levels (Küçükçekmece sample). Unpublished MSc Thesis, Yıldız Teknik University Graduate School of Social Sciences, İstanbul.

[6] Brown, B. B. (2003). Employees' Organizational Commitment and Their Perception of Supervisors` Relations-Oriented and Task-Oriented Leadership Behaviors, Dissertation, Faculty of the Virginia Polytechnic Institute and State University, Virginia, 41.

[7] Çetin, M.Ö. (2004). Organziational Culture and Organizational Commitment, Ankara: Nobel Publication.

[8] Demircan, N., Ceylan, A. (2003). Organizational Trust Concept, Reasons and Results. Celal Bayar University İ.İ.B.F Management and Economy, 10 (2), 139-150.

[9] Dirks, K. T., Ferrin, D. L. (2001). "The Role of Trust in Organizational Settings". Organization Science, 12(4), 450-467.

[10] Durukan, S., Akyürek, Ç., ve Coşkun, E. (2010). Determination of organizaitonal trust, strengthening and commitment levels of nurses working in Adults' Hospital of Hacettepe University. Süleyman Demirel University Journal of faculty of economics and administrative sciencesi, 15 (3), 411-434.

[11] Eren, E. (2011). Management and organization, modern and cultural approaches. Beta Publication, İstanbul. 
[12] Erdoğmuş, H. (2006). Relationship between personal characteristics and organizational commitment of directors working in private-state primary schools. (Unpublished MSc thesis). Marmara University, Graduate School of Education Sciences, İstanbul.

[13] Ersoy, S., Bayraktaroğlu, S. (2010). Current issues in organizational commitment and organizational behaviour. İstanbul: Ekin Publication, 1-18.

[14] Fard, G.P. and Fariba, K. (2015). The Relationship between Organizational Trust and Organizational Silence with Job Satisfaction and Organizational Commitment of the Employees of University, International Education Studies, 8, 11, 219-227.

[15] Gören, T. ve Sarpkaya, P.Y. (2014) The level of organizational commitment of the teachers in primary schools in Aydin, Journal of Educational Sciences, 40, 69-87.

[16] Huff, L. ve L. Kelley (2003). Levels of Organizational Trust in Individualist Versus Collectivist Societies: A Seven Nation Study, Organization Science, 14, 1.

[17] İşcan, Ö.F. ve Sayın,U. (2010). Relationship between organizational justice, work satisfaction organizational trust, Atatürk University Journal of Economics and Administration, 24,4 .

[18] Kaneshiro, P. (2008). Analyzing the organizational Justice, Trust, and Commitment Relationship in a Public Organization: Submitted to North central University, University Microfilms. The Humanities and Social Sciences, 14-20.

[19] Khatibi,A., Asadi, H. and Hamidi, M. (2009) The Relationship Between Job Stress and Organizational Commitment in National Olympic and Paralympic Academy, World Journal of Sport Sciences 2 (4): 272-278.

[20] Khorshid, S., and Yazdani, H. (2012). The studying of relationships among trust, reciprocity and organizational identification with considering the moderated effect of organizational commitment. Transformation management journal, 4(7), 62-90.

[21] Koç, H. ve Yazıcıoğlu, İ. (2011). Relationship between trust in director and work satisfaction, Comparison of state and private sectors. Journal of Doğuş University, 12 (1), 46-57.

[22] Lambert, E. and E.A. Paoline, 2008. The Influence of Individual, Job and Organizational Characteristics on Correctional Staff Job Stress, Job Satisfaction and Organizational Commitment, Criminal Justice Review, (33)4: 541-564.

[23] Manion, J. (2004). Strengthening organization commitment: Understanding the concept as a basis for creating effective workforce retention strategies. Health Care Manager, 23, $167-176$.

[24] Mathieu, J.E., and D.M. Zajac, 1990. A review and meta-analysis of the antecedents, correlates and consequences of organizational commitment Psychological Bulletin, 108(2): 171-194.

[25] Meyer, J.P. and N.J. Allen, 1990. The measurement and antecedents of affective, continuance and normative commitment to The Organization. Journal of Occupational Psychol., 63: 1-18.
[26] Meyer, J. P., \& Allen, N. (1991). A three-component conceptualization of organizational commitment. Human Resource Management Review, 1, 61-89.

[27] Meyer, J. P., Allen, N. J. and Smith, C. A. (1993). Commitment to organizations and occupations: extension and test of a three component conceptualization. Journal of Applied Psychology, 78(4), 538-551.

[28] Meyer, J. P., \& Allen, N. J. (1997). Commitment in the workplace: Theory, research, and application. Thousand Oaks, CA: Sage, pp.11.

[29] Meyer, J. P., \& Herscovitch, L. (2001). Commitment in the workplace: Toward a general model. Human Resource Management Review, 11, 299-326.

[30] Morgan, R.M. and Hunt, S.D. (1994) "The Commitment Trust Theory of Relationship Marketing”, Journal of Marketing, 58(3), 20-39, 25.

[31] Mowday, R. T., Porter, L. W., \& Steers, R. M. (1982). Employee-organization linkages. New York: Academic Press, pp. 27.

[32] Neves, P. \& Caetano A. (2006). Social Exchange Processes in Organizational Change: The Roles of Trust and Control, Journal of Change Management. 6, 4, 351-364.

[33] Omarov, A. (2009). Organizational Trust and Work Satisfaction: An application in a private sector, Dokuz Eylül University Graduate School of Social Sciences Department of Busness, İzmir, (Unpublished MSc thesis).

[34] Ruyter, K., and M. Wetzels. (1999). Commitment in auditor-client relationships: Antecedents and consequences. Accounting, Organizations and Society 24 (1): 57-75

[35] Shaw, R.B. (1997). Trust in Balance: Building Successful Organizations on Results, Integrity and Concern, Jossey-Boss Publishers, San Francisco.

[36] Shaw, J. D., Delery, J. E., \& Abdulla, M. H. A., (2003). Organizational commitment and performance among guest workers and citizens of an Arab country. Journal of Business Research, 56, 1021- 1030.

[37] Sheik-Mohamed, L., Mohiadeen, A. K. M., \& Anisa, H. (2012). Relationship among Organizational Commitment, Trust and Job Satisfaction: An Empirical Study in Banking Industry. Research Journal of Management Sciences, 1(2), $1-7$.

[38] Stup, R. E. (2005). Human resource management and dairy employee organizational commitment. The Pennsylvania State University, Pennsylvania.

[39] Taşkın, F., Dilek, R. (2010). A Field Research on Organizational Trust and Commitment, Organizasyon ve Yönetim Bilimleri Dergisi, 2, 1.

[40] Tella, A., Ayeni, C. O., \& Popoola, S. O. (2007).Work motivation, job satisfaction and organisational commitment of library personnel in academic and research libraries in Oyo State, Nigeria. Library Philosophy and Practice, 1-16.

[41] Top, M., Akdere, M. and Menderes Tarcan, M. (2015) Examining transformational leadership, job satisfaction, organizational commitment and organizational trust in Turkish hospitals: public servants versus private sector employees, The International Journal of Human Resource 
Management, 26, 9, 1259-1282.

[42] Topaloğlu, I. G. (2010). Relationship between organizational trust and organizational commitment of transactors in terms of justice and ethics. MSc thesis, Atılım University Graduate School of Socal Sciences, Ankara.

[43] Vakola, M., Bouradas, D., \& Nikolaou, I. (2011). The role of silence on employees' attitudes "the day after" a merger. Emerald Group Publishing Limited, 40(6), 723-741.

[44] Vineburgh, J. H. (2010). A study of organizational trust and related variables among faculty members at HBCUs.
(Doctoral dissertation). University of Iowa, pp.18.

[45] Wasti, S.A. (2000, 25-27 May1s). Validity and reliability analysis of three dimensional organizational commitment scale of Meyer and Allen. 8th National Management and Organization Conference - Presentations, Nevşehir.

[46] Y1ldiz, S.M. (2011) The Relationship among Internal Marketing, Job Satisfaction and Organizational Commitment: An Investigation of Coaches Working in Sports Schools, Selcuk University Journal of Physical Education and Sport Science,13(2): 216-225 